\title{
ADAPTATION OF CRIMINAL JUSTICE LEGISLATION \\ OF UKRAINE TO ACQUIS COMMUNAUTAIRE OF THE EUROPEAN UNION: BASIC PRINCIPLES AND IMPLEMENTATION ISSUES
}

\author{
АДАПТАЦІЯ ЗАКОНОДАВСТВА УКРАНИ В ГАЛУЗІ КРИМІНАЛЬНОГО \\ СУДОЧИНСТВА ДО ПОЛОЖЕНЬ ЗАКОНОДАВСТВА ЄВРОПЕЙСЬКОГО СОЮЗУ: \\ ОСНОВНІ ПРИНЦИПИ ТА ЗАВДАННЯ
}

\author{
Kryzhanivskyi V.V., PhD in Law, associate professor, \\ Civil Procedure Department of the Institute of Law, \\ Taras Shevchenko National University of Kyiv \\ Shabunina V.V., associate professor, \\ head of the foreign languages department \\ for History and Philosophy faculties, \\ Taras Shevchenko National University of Kyiv
}

Frolova Daria, paralegal

Main Directions of Ukrainian Foreign Policy stipulate that the development of relations with West-European nations creates conditions for retrieval of traditional political, economic, cultural and spiritual activities. Thus, this cooperation will be the basis for increasing the participation of Ukraine in the European structures and the future integration of its economy into the European and world economy. Despite the fact that Ukraine was not obliged to adapt its legislation to the European Union (hereinafter - EU) acquis, there were numerous attempts and efforts of the Ukrainian government to realize these plans. In particular, the establishment of the National Council for adaptation of Ukraine to the EU legislation.

The EU Association Agreement does not provide an obligation to adapt criminal legislation to the EU acquis. Though, harmonization of the Ukrainian legislation is required promoting the struggle against money laundering and financing of terrorism, drug trafficking and corruption. Accordingly, the approximation of Ukrainian criminal procedural legislation to the EU acquis is unavoidable due to the need to implement all the objectives of cooperation between Ukraine and the EU.

There are certain basic principles deriving from the EU acquis and judicial practice and integrated into the legislation of the EU memberstates. Mention should be made of the principle of subsidiarity, proportionality, of mutual recognition (which is of utmost importance in criminal justice), the principle of European territoriality, etc. The authors provide with the information on the measures undertaken by Ukraine in order to adapt its legislation in the sphere criminal justice to existing norms and standards of the EU.

Key words: acquis communautaire, criminal justice, adaptation, criminal procedure, principle

Основні напрямки зовнішньої політики України передбачають, що розвиток відносин із західноєвропейськими країнами створює умови для відновлення традиційної політичної, економічної, культурної та духовної діяльності. Таким чином, ця співпраця стане основою для збільшення участі України у європейських структурах та майбутньої інтеграції її економіки у європейську та світову економіку. Незважаючи на те, що Україна не була зобов'язана адаптувати своє законодавство до законодавства ЄС, було чимало спроб та зусиль українського уряду реалізувати ці плани. Зокрема, створення Національної ради з адаптації України до законодавства ЄС.

Угода про асоціацію з ЄС не передбачає обов'язку адаптувати кримінальне законодавство до законодавства ЄС. Хоча, необхідна гармонізація українського законодавства для сприяння боротьбі з відмиванням грошей та фрінансуванням тероризму, торгівлі наркотиками та корупцією. Відповідно, наближення українського кримінального процесуального законодавства до законодавства ЄС є неминучим через необхідність реалізації всіх цілей співпраці між Україною та ЄС.

Існують певні основні принципи, що випливають із законодавства ЄС та судової практики та інтегровані у законодавство державчленів ЄС. Слід відзначити принцип субсидіарності, пропорційності, взаємного визнання (що є надзвичайно важливим у кримінальному судочинстві), принцип європейської територіальності тощо. Автори зазначають, які заходи вживаються Україною з метою адаптації законодавства у сфері кримінального правосуддя до існуючих норм та стандартів ЄС.

Ключові слова: положення законодавства, кримінальне судочинство, адаптація, кримінальний процес, принцип

1. LEGISLATIVE FRAMEWORK OF ADAPTATION OF UKRAINIAN LEGISLATION TO THE EUROPEAN UNION ACQUIS COMMUNAUTAIRE

Ukraine's position towards the EU was first presented in the Main Directions of Ukrainian Foreign Policy, approved by the Supreme Council of Ukraine in 1993. In Part II The Principles Of Ukraine's Foreign Policy of the Directions it is stipulated that the development of relations with WestEuropean nations creates conditions for retrieval of traditional political, economic, cultural and spiritual ties between Ukraine and European civilization, accelerated democratization, market reforms and incipience of national economy. However, this cooperation will be the basis for increasing the participation of Ukraine in the European structures and the future integration of its economy into the European and world economy [1].

Intention of Ukraine to join the EU was demonstrated in 1994 via signing of the Agreement on Partnership and Cooperation between Ukraine and the European Union on 16 June 1994. However, the provisions of this
Agreement contain mainly obligations of cooperation between the parties[2]. Direct obligations of Ukraine to adapt its legislation to acquis were not provided by any international agreements of Ukraine by 2014.

However, Ukrainian national legislation has contained extensive legal framework for the adaptation to the EU acquis. Decree of the President of Ukraine On Approval of the Strategy of Ukrainian integration into the European Union on 11 November 1998 provided the need for adaptation of Ukrainian legislation to the acquis communautaire. Para.1 of the Decree stated that such adaptation means approximation to the modern European system of law that will ensure the development of political, business, social and cultural activities in Ukraine, as well as the economic development of the country within the EU. Moreover, it will facilitate welfare of citizens, bringing it to the level established in the EU [3].

Despite the fact that Ukraine was not obliged to adapt its legislation to the EU acquis, there were numerous attempts and efforts of the Ukrainian government to realize these 
plans. In particular, the establishment of the National Council for adaptation of Ukraine to the EU legislation, unified plan of coordination and control within the legislative bodies concerning adaptation work. In addition, every year State Budget of Ukraine contains cost of financing measures for the adaptation [4].

Under art.11 (2) of the Law of Ukraine On The Principles of Domestic And Foreign Policy Ukraine`s integration into European political, economic and legal system via membership in the European Union is one of the basic principles of the Ukrainian foreign policy [5]. In 2014, Ukraine signed an Association Agreement with the EU. It confirmed the obligation of Ukraine to adapt its legislation to the EU acquis, in particular art.1, 58, 114, 153 of the Agreement [6]. Mostly it concerns legislation governing trade issues between the parties.

The question of relevant adaptation of Ukrainian legislation to European standards in general is still on agenda. In particular, there are some discussions in the area of criminal procedural law. The EU Association Agreement does not provide an obligation to adapt this part of legal framework to the EU acquis. Though, harmonization of the Ukrainian legislation is required promoting the struggle against money laundering and financing of terrorism, drug trafficking and corruption [7]. Accordingly, the approximation of Ukrainian criminal procedural legislation to the EU acquis is unavoidable due to the need to implement the above mentioned objectives of cooperation between Ukraine and the EU.

\section{REGULATION OF THE CRIMINAL PROCEDURE} IN ACQUIS COMMUNAUTAIRE OF THE EUROPEAN UNION

Previously the EU basic treaties did not contain provisions on cooperation in criminal procedure, mostly concentrating on integration in the socio-economic sphere. Due to the current globalization this area of international cooperation gained strategic importance as aimed at freedom, security and justice. Criminal procedure in the EU countries is mostly regulated by their national legislation. Though, we may distinguish some basic principles deriving from the EU acquis and judicial practice and penetrating into the EU members' legislation.

Art. 83 of the Treaty on the Functioning of the European Union (hereinafter - the Treaty) entitles the European Parlament and Council to establish minimum rules concerning the definition of criminal offences and sanctions for serious crimes across the border, resulting from the kind or impact of such offences or from a special need to combat them together. This position is a reflection of the principle of subsidiarity, which is that in all cases if the objectives of the EU cannot be achieved by the Member States on their own, but together, it becomes a matter of the EU [8, p. 94]. Therefore, the scope of EU criminal justice should apply only to those crimes that are particularly serious, and for which EU action is justified [9].

The principle of subsidiarity provides that in accordance with Art. 82 (2) of the Treaty harmonization in the EU should be limited to cross-border cases [10]. The principle of subsidiarity provides presumption in favor of the actions of the Member State which may be rebutted only if it is proved that the matter involves a clearly defined cross-border element. If the problem is local in nature or only indirectly affects the interests of more than one Member State, the subsidiarity principle is not to be applied [11 p.40].

According to the principle of proportionality under Art. 5 (4) of the Treaty, the content and form of Union action shall not exceed what is necessary to achieve the objectives of the Treaties. The principle of proportionality means that measures must be appropriate and necessary in order to achieve the goal. In other words, everything that goes beyond the goal does not conform to this principle. Thus, the application of criminal law in situations that could be effectively solved by other means (e.g. by means of civil or administrative law) constitutes a violation of the principle of proportionality.
In this sense, the principle of proportionality serves as one of the principles of criminal law (principle of ultima ratio) $[12$, p. 50$]$.

Another important principle for criminal justice in the EU is the principle of mutual recognition. V. Mitsilegas suggests that the principle of mutual recognition creates extraterritoriality promoting freedom, security and justice, as the judgment of the Member State can be executed outside its boundaries [13, p. 470]. The best example of the mutual recognition is the system introduced by the Framework Decision on the European arrest warrant. After the adoption of the Lisbon Treaty there was the question of the compatibility of the principle of mutual recognition with provisions of the Charter of Fundamental Rights of the Union raised the case Ciprian Vasile Radu. In this case, the Court was asked whether the national court may deny mutual recognition for breach of fundamental rights. In this case, the Court declined and concluded that compliance with Art. 47, 48 of the Charter does not require the judicial authority of the Member State refused to fulfill the European arrest warrant issued for the purpose of prosecution on the grounds that the requested person was heard in court before issuing this warrant [14].

However, the principle of mutual recognition is still not admitted by all the European national criminal justice systems. In particular, some problems arise from the admissibility of evidence and procedural guarantees for the suspects or defendants in transnational criminal proceedings, conducted pursuant to the principle of European territoriality [15, p. 166].

As for the practice of the European Court of Justice (hereinafter - the Court), court jurisdiction had not covered the field of criminal justice for a long time. After the entry into force of the Lisbon Treaty and the abolition of Art. 35, 68 , which imposed restrictions on the jurisdiction of the Court of Justice, the Court received the general jurisdiction to grant prejudicial findings in the area of freedom, security and justice [16]. Under the Lisbon Treaty, the field of criminal justice will become part of the EU law, any national court or tribunal will appeal to the Court of Justice for prejudicial conclusion. However, the transitional provisions envisaged that full jurisdiction will not apply during five years after the Lisbon Treaty enter into force. Till 2016 the Court of Justice approved 13 prejudicial decisions in the field of police and judicial cooperation in criminal matters concerning the interpretation of the Directive provisions [17, p. 65].

It should be noted that although the Court had no jurisdiction over judicial cooperation in civil and criminal matters, it repeatedly emphasized in its decisions that the relations between Member States and Community institutions were based on reciprocal duty of fair cooperation [18]. In Criminal proceedings against Maria Pupino the Court noted that the Union would be difficult to perform its task if the principle of loyal cooperation (loyal cooperation) was not required in police and judicial cooperation in criminal matters pursuant to section VI of the Treaty on European Union, which, moreover, entirely based on cooperation between member states and institutions [19]. This decision changed the usual vision of the rule of EU law with regard to matters relating to the third pillar. The Court formulated it in this case as a demand to interpret national law in accordance with the objectives of the EU legislation. Further confirmation of this principle was provided in Sison against Council, where the Court stated that the principle of fair cooperation (good faith cooperation) is a principle of general application and applies to the field of police and judicial cooperation in criminal matters based exclusively on cooperation between member states and institutions [20 p.110].

The complexity to divide competences between the pillars in the context of criminal proceedings is also confirmed in the case of the Court [21] on the implementation of the European Parliament and Council 2005/35/EC from 7 September 2005 on pollution by ships and imposing 
penalties for infringements. Greece, Cyprus and Malta opposed the harsh criminal sanctions against the ships that were sources of pollution. In the framework of the third pillar they could veto. The question arose not only concerning the authority of Community to adopt the law in criminal cases, but also the necessity of criminal law to protect the objectives of the Community or the possibility of other forms of intervention. The Court ruled that the application of effective, appropriate and dissuasive criminal penalties by the competent national authorities is essential for combating serious environmental crime in general and in the transport sector, particularly sea transport and protection. It also confirmed that the EU may require the Member State to impose such penalties in order to ensure the effectiveness of rules, notwithstanding whether criminal ones or the rules of criminal procedure fall within the competence of the Community or not. Thus, the Court of Justice held that the Community has its own legislative competence under the common transport policy for criminal law measures to achieve the objectives of Directive 2005/35/EC (amended by Directive 2009/123 / EC) [22].

In 2009 the European Parliament adopted a recommendation to the Council on the development of criminal justice in the EU, where the basic principle of such development is respect to fundamental rights. The Parliament called on the Council to adopt the legal instruments necessary to complete its implementation and ensure the approximation of minimum standard rules concerning certain aspects of criminal procedural law [23].

3. THE ADAPTATION OF THE UKRAINIAN CRIMINAL JUSTICE LEGISLATION TO ACQUIS COMMUNAUTAIRE

Regulation of the response to crime and corruption as one of the priority areas of cooperation with the EU has undergone a conceptual change, because since 2012 there were adopted new legislative acts and significant new legal institutions were established. Most of them have been previously unknown to the Ukrainian national law. They correspond to the European standards, as well as represent a new ideology of criminal justice, based on priority of human rights and freedoms, their protection.

Among these laws the 2012 Criminal Procedure Code of Ukraine shall be mentioned foremost, which has become the foundation for further legislative innovations in the field of criminal justice. Adversarial criminal proceedings; delineation of criminal procedural functions; substantial expansion of judicial review during the preliminary investigation and procedural capabilities of the defense regarding the collection of evidence; implementation of the principle of immutability of the prosecutor in criminal proceedings; radical change in the model of the criminal proceedings; regulation of tacit prosecution activity to verify the allegations of crime and collect evidence, known as covert investigative (detective) actions; implementation of the consensual procedures, in particular, agreements in criminal proceedings that provide opportunities to effectively protect the private interests of participants in criminal proceedings and also to resolve criminal legal conflict; widespread use of means of fixation in the exercise of criminal proceedings etc. [24]

We cannot omit mentioning changes to Criminal Procedure Code of Ukraine in 2016, provided by the Law of Ukraine On Amendments to the Criminal and Criminal Procedure Codes of Ukraine to Implement the Recommendations Contained in the 6th report of the European Commission on Implementation of the Action Plan by Ukraine to Liberalize EU Visa Regime for Ukraine Concerning Improvement of the Seizure and Special Confiscation Procedures. This act substantially changed the seizure procedure, in particular via special confiscation [25]

Adaptation of the Ukrainian legislation in context of European integration is reflected in the latest criminal procedural legislation. For instance, the Laws of Ukraine On Legal Aid, On the Right to a Fair Trial, On Probation etc. significantly altered regulation within the criminal justice system. The new institutions were established including the National Police, National Anti-Corruption Bureau of Ukraine. Their functionality is aimed at effective criminal justice according to European values and standards of human rights, public expectations regarding public response to corruption [26, p. 113].

Analysis of the strategic reforming directions in the Ukrainian criminal justice in order to adapt it to the EU acquis, allows identifying priorities of adaptation and modernization of legislation in this area.

In particular, it should emphasize the need for a proper legal framework for cybercrime countermeasures. Understanding the utmost importance to solve this problem led to the adoption of Cybersecurity strategy of Ukraine approved by the 2016 Decree of the President of Ukraine and aimed to create conditions for the safe functioning of cyberspace, its use for the benefit of individuals, society and the state [27].

According to para. 4.5 of the Strategy in order to ensure cybersecurity of Ukraine State shall address to cybercrime countermeasures, in particular creation of an effective and easy contact center to report cases of cybercrime and fraud in cyberspace, improve efficiency response to cybercrime law enforcement bodies, including their regional units; improving procedural arrangements for the collection of evidence in electronic form relating to crime, improving classification methods, tools and techniques to identify and fix cybercrime, expert research; blocking operators and providers of telecommunications determined (identified) information resources (information services) by the court; the possibility of settling the urgent implementation of procedural actions in real time with the use of electronic documents and digital signatures; implementation of the scheme (protocol) coordination of law enforcement agencies to combat cybercrime; training of judges (judicial investigation), investigators and prosecutors to work with the evidence relating to the offense received electronically and related to cybercrime; establishment of special procedure to intercept telecommunications in case of cybercrime investigations etc [28].

Attention shall be paid to the fact that mentioned measures require implementation of criminal procedural norms enabling their realization on the stage of the pre-trial investigation of cybercrime and court proceedings. Some of them are not provided by the current criminal procedural legislation of Ukraine yet. That makes this area promising in course of development and reception of the European experience.

We also should emphasize on the urgency to establish effective witness and victim protection against threats associated with their participation in criminal proceedings in respect of grave and especially grave crimes. The value of this task as a guarantee of rights and legal interests of a person in criminal proceedings and guarantees of justice led to its consolidation in the art. 22 of the Association Agreement, which include the provision that the parties will continue to develop cooperation, inter alia, on matters relating to the protection of witnesses and victims [29].

The European approach to witness and victim protection is based upon the obligation of the state to provide such protection. Therefore, in most states-members of EU there are witness and victim protection programmes (national, federal, regional). Protection of witness and victim in criminal proceedings in almost all states-members of EU is a resourceintensive program, which provides a number of measures to ensure the safety of these persons used at different stages of law enforcement agencies that implement this program. Risk management is used for this purpose, which consists of certain phases of work. In the first stage threats to the witness are evaluated. The evaluation results of these threats are important to address issues including witness protection programs 
and selection of specific protective measures. In the second stage risk is estimated via classifications of its level (high, medium) and measures to be implemented are defined. In the third stage an analysis of risk factors and assessing their value are conducted in order to determine the likelihood of undesirable consequences that may also affect the goal of the criminal justice. Risk analysis includes assessment and their methods of reducing possible adverse effects that may be prevented by law enforcement officers. The fourth phase includes control of security measures applied to a witness [30].

In Ukraine protection of witness and victim is regulated by the 1993 Law of Ukraine On the Safety of Persons Involved in Criminal Proceedings [31]. The Criminal Procedure Code of Ukraine stipulates certain provisions relating to the right to protection as an element of the legal status of the participants of criminal proceedings; the possibility of a closed court session; peculiarities of individual identification, disclosure of material to the another party, appealing decisions, actions or inactions of investigator or prosecutor; video conference during the proceedings. The duty of the investigating judge to take the necessary measures to ensure the safety of persons is also prescribed in the Ukrainian law [32]. However, in practice protection of participants in criminal proceedings still requires significant improvement and the introduction of new mechanisms to protect witnesses and victims [33, p. 90].

But the main problem for the Ukrainian criminal justice in particular and legal system in the whole is the presence of corruption risks. They exist due to the imperfection of legislation regulating criminal proceedings. In particular, it is caused by deficient legislative technique that creates the preconditions for variety of approaches to legal interpretation, the lack of uniform standards of legal technology to ensure the quality of criminal procedural decisions, the opacity of certain decision-making and procedural commission proceedings, inadequate mechanisms of public prosecution measures etc [34, p. 115].

In order to reduce the mentioned risks numerous efforts are put by the Ukrainian authorities, in particular the implementation of anti-corruption expertise of legal acts. It is obligatory towards the draft laws of Ukraine, acts of the President of Ukraine, other regulations, developed by the Cabinet of Ministers of Ukraine. As one of the most important preventive measures in combating corruption, as international practice shows, anti-corruption expertise of legislation is very important because corruption risks are put within legislation [35, p. 117].

Summary

Though, as R. Lahti mentions, differentiation and legal pluralism are the realities of the criminal justice in the EU [36, p. 354]. It means that adaptation of the Ukrainian legislation to acquis communautaire in the area of criminal justice is encumbered by the absence of integrated and systematic legal framework within the EU law. Nevertheless, it does not eliminate necessity to take into account the general principles that have already arisen from the EU legal framework in this field.

Considering the permanent reforming of the justice system in Ukraine it is especially urgent to address to the EU experience despite the absence of direct obligation of Ukraine to adapt its criminal procedural legislation to EU acquis. However, objectives provided by the Assosiation Agreement between Ukraine and the European Union can be achieved only due to the systematic and conceptional evolution of the Ukrainian law, in particular, in the field of criminal justice.

\section{REFERENCES}

1. Decree of the Supreme Council of Ukraine On the Main Directions of Ukrainian Foreign Policy (02.07.1993 № 3360-XII), The Voice of Ukraine, 1993.

2. 1994 Partnership and Cooperation Agreement between the European Communities and their Member States, and Ukraine, Official Bulletin of Ukraine, 2006, № 24.

3. Decree of the President of Ukraine On Approval of the Strategy of Ukrainian integration into the European Union (11.06.1998 № 615/98), Official Bulletin of Ukraine, 1998, № 24.

4. Law of Ukraine On the Concept of National Adaptation Program of Ukraine's legislation to the Legislation of the European Union (21.11.2002 № 228-IV), Official Bulletin of Ukraine, 2002, № 50.

5. Law of Ukraine On The Principles Of Domestic And Foreign Policy (01.07.2010 № 2411-VI), Official Bulletin of Ukraine, 2010 , № 55.

6. Association Agreement between the European Union and the European Atomic Energy Community and their member states, of the one part, and Ukraine, of the other part, Official Bulletin of Ukraine, 2014, № 75.

7. Association Agreement between the European Union and the European Atomic Energy Community and their member states, of the one part, and Ukraine, of the other part, Official Bulletin of Ukraine, 2014, № 75.

8. Mykiyevych M. Andrusevych N., Budyakova T. The EU Environmental Law, Lviv, 2004, p.94.

9. Developing a Criminal Justice Area in the European Union, 2014. URL: http://www.europarl.europa.eu/RegData/etudes/etudes/ join/2014/493043/IPOLLIBE_ET(2014)493043_EN.pdf

10. Consolidated Version Of the Treaty on the Functioning of the European Union, Official Journal of the European Union, 2012, C 326/47.

11. Öberg J., Subsidiarity and EU Procedural Criminal Law, 5 European Criminal Law Review 19, 2015, p. 40

12. Neagu N., European (Criminal) Law v. National (Criminal) Law - a Two Way Street, Law Review, vol. II, iss. 2, 2015 , p. 50.

13. Mitsilegas V., The Symbiotic Relationship Between Mutual Trust and Fundamental Rights in Europe's Area of Criminal Justice. New Journal of European Criminal Law (special issue), 2015, p.470.

14. Judgment of the European Court of Justice (Grand Chamber) in case C-396/11 Ciprian Vasile Radu (29 January 2013). Available at SSRN: http://curia.europa.eu/juris/liste.jsf?language=en\&num=C-396/11

15. Banach-Gutierrez J.B., Globalised Criminal Justice in the European Union Context: How Theory Meets Practice, New Journal of European Criminal Law, Vol. 4, iss. 1-2, 2013, 154-167, p.166.

16. Press Release No 104/09, Court of Justice of the European Communities, 2009 Available at SSRN: http://europa.eu/rapid/press-release CJE-09-104_en.html

17. Bench N., The Principles Of Criminal Justice In The European Union, The Journal of European and Comparative Law, Vol. 3, 2016, p. 65 18. Judgment of the European Court of Justice (Fifth Chamber) in case C-339/00 Ireland v Commission of the European Communities (16 October 2003), European Court reports, 2003, p. I-11757.

19. Judgment of the European Court of Justice (Grand Chamber) in case C-105/03 Criminal Proceedings against Maria Pupino (16 June 2005). Available at SSRN: http://eur-lex.europa.eu/legal-content/EN/TXT/?uri=CELEX\%3A62003CJ0105

20. Irinyeyeva V., The Criminal Justice System In The European Union, dissertation submitted for the degree of Candidate of Juridical Sciences, Kyiv, 2012, p. 110.

21. Judgment of the European Court of Justice (Grand Chamber) in case C-308/06 Intertanko and Others (3 June 2008). Available at SSRN: http://curia.europa.eu/juris/liste.jsf?language=en\&num=C-308/06

22. Directive2005/35/EC of the European Parliament and of the Council of 7 September 2005 on ship-source pollution and on the introduction of penalties for infringements, Official Journal of the European Union, 2005, L 255/11.

23. European Parliament recommendation 2009/2012(INI) to the Council on the development of an EU criminal justice area. Available at SSRN: http://www.europarl.europa.eu/sides/getDoc.do?type=TA\&reference=P6-TA-2009-0386\&language=EN\&ring=A6-2009-0262 
24. Criminal Procedure Code of Ukraine (13.04.2012 № 4651-VI), Official Bulletin of Ukraine, 2012, № 37.

25. Law of Ukraine On Amendments to the Criminal and Criminal Procedure Codes of Ukraine to Implement the Recommendations Contained in the 6th report of the European Commission on Implementation of the Action Plan by Ukraine to Liberalize EU Visa Regime for Ukraine Concerning Improvement of the Seizure and Special Confiscation Procedures (18.02.2016 № 1019-VIII), Official Bulletin of Ukraine, 2016 , № 18.

26. Shilo O. Adaptation Problems Of Criminal Procedural Legislation Of Ukraine To European Union Law, Bulletin of the National Academy of Sciences of Ukraine, Kharkiv, 2016, № 2, p. 113.

27. Decree of the President of Ukraine On the decision of the National Security and Defense of Ukraine on January 27, 2016 on the Strategy of Cybersecurity of Ukraine (15.03.2016 № 96/2016), Official Bulletin of Ukraine, 2016, № 23.

28. Decree of the President of Ukraine On the decision of the National Security and Defense of Ukraine on January 27, 2016 on the Strategy of Cybersecurity of Ukraine (15.03.2016 № 96/2016), Official Bulletin of Ukraine, 2016, № 23.

29. Association Agreement between the European Union and the European Atomic Energy Community and their member states, of the one part, and Ukraine, of the other part, Official Bulletin of Ukraine, 2014, № 75.

30. Krasnova K. Witness protection in the EU Member States. Available at SSRN: http://sbsnews.eu/ru

31. Law of Ukraine On the Safety of Persons Involved in Criminal Proceedings (23.12.1993 № 3782-XII), The Voice of Ukraine, 1994.

32. Criminal Procedure Code of Ukraine (13.04.2012 № 4651-VI), Official Bulletin of Ukraine, 2012, № 37.

33. Orlean A. The Procedure of Providing Protection to Participants in Criminal Proceedings: Adaptation of Ukraine to European standards, Actual problems of law, 2016, Vol. 3, p. 90.

34. Shilo O. Adaptation Problems Of Criminal Procedural Legislation Of Ukraine To European Union Law, Bulletin of the National Academy of Sciences of Ukraine, Kharkiv, 2016, № 2, p. 115.

35. Shilo O. Adaptation Problems Of Criminal Procedural Legislation Of Ukraine To European Union Law, Bulletin of the National Academy of Sciences of Ukraine, Kharkiv, 2016, № 2, p. 117.

36. R. Lahti, Harmonization of Criminal Law and Its Relation to National Law. Problems of Substance and in the Administration of Justice, w: Györgyi Kálmán ünnepi kötet [Festschrift Györgyi Kálmán]. Szerkesztö: Gellér Balázs. Bibliotheca luridica, Az ELTE Államés Jogtudományi Karának tudományos kiadványai Libri Amicorum 11, Budapest 2004, p. 354. 